\title{
Saving the baby while discarding the bathwater: the application of policy coherence for development analysis to payment for watershed services
}

\author{
Salvar al bebé mientras se descarga el agua de la bañera: aplicación del \\ análisis de coherencia de políticas para el desarrollo en el pago por \\ servicios de cuencas hidrográficas
}

\author{
Harlan Koff' and Carmen Maganda ${ }^{*}$
}

1 University of Luxembourg. IPSE Research Unit. Esch-Belval, Luxemburgo.
2 Instituto de Ecología, A. C. Red Ambiente y * Corresponding author. carmen.maganda@inecol.mx Sustentabilidad. Xalapa, Veracruz, México.

\begin{abstract}
One of the most debated tools for the implementation of sustainable development is "payment for ecosystem services", of which "payment for watershed services" (PWS) is one of the most developed. While proponents argue that such payments provide market value to the services that ecosystems provide for development, opponents claim that this approach commodifies the environment and promotes inequalities. This article presents an analysis of PWS programs by applying methodologies based on policy coherence for development (PCD), defined as a policy tool aimed at eliminating incoherence within sustainable development strategies that undermine their effectiveness as well as between such strategies and other policy arenas, which are also considered harmful to sustainability. By employing a PCD methodology, the article aims to identify policy mechanisms that undermine PWS programs so that stakeholders can make adjustments, thus, metaphorically ensuring that "the baby" (PWS) is not discarded with "the bathwater" (policy incoherence for sustainable development).
\end{abstract}

KEYWORDS: Antigua river basin, Mexico, payment for ecosystem services (PES), payment for watershed services (PWS), policy coherence for development (PCD), Veracruz.

\section{RESUMEN}

Una de las herramientas más debatidas para la implementación del desarrollo sostenible es el "pago por servicios ecosistémicos", de los cuales el "pago por servicios de cuencas hidrográficas" (PWS, por sus siglas en inglés) es uno de los más desarrollados. Autores a favor argumentan que tales pagos proporcionan valor de mercado a los servicios que los ecosistemas brindan para el desarrollo, pero los opositores afirman que este enfoque mercantiliza el ambiente y promueve las desigualdades. Este artículo presenta un análisis de los programas de PWS mediante la aplicación de metodologías basadas en la coherencia de políticas para el desarrollo (PCD), definida como una herramienta de políticas dirigida a eliminar la incoherencia en las estrategias de desarrollo sostenible que socavan su efectividad, así como entre dichas estrategias y otras áreas de políticas, que también se consideran perjudiciales para la sostenibilidad. Al emplear la metodología de PCD, este trabajo apunta a identificar los mecanismos de políticas que socavan los programas de PWS para que las partes interesadas puedan realizar ajustes, asegurando metafóricamente que "el bebé" (PWS) no se vaya por el desagüe junto con el "agua de la bañera" (metáfora de una política incoherente para el desarrollo sostenible).

Palabras Clave: cuenca del río Antigua, México, pago por servicios ecosistémicos, pago por servicios de cuencas, coherencia de políticas para el desarrollo, Veracruz. 


\section{INTRODUCTION}

In his 2008 article in Environment and Planning $C$ (Government and Policy), Andrew Jordan (2008) illustrated through a comprehensive review of the literatures on sustainable development and governance how these two concepts provide a weak foundation for development policies because they are muddled and contested terms. "Sustainable development" generally refers to "development that meets the needs of the present without compromising the ability of future generations to meet their own needs." (Brundtland Commission, 1987) which focuses on allocation of resources including common goods. "Governance" is defined as "the changing relationships between actors situated at different territorial levels, both from the public and the private sectors" within decision-making processes (Marks, 1993) with a focus on shared responsibilities and interactions.

Despite these opaque definitions, these paradigms are the pillars of the 2030 Agenda for Sustainable Development (United Nations, 2015), which aims to foster transformative development, defined as universal development processes that promote human rights and socio-environmental justice at the local level and address power imbalances in the global political arena (Martens, 2015). This agenda surpasses traditional notions of "sustainable development" and "governance" in its aims and scope.

The 2030 agenda normatively guides development cooperation in the global arena and in principle, it provides the benchmark for "successful" policymaking in the field of sustainable development (Adger et al., 2003). This has been problematic, however. Cross-regional research has in fact shown how "sustainability" and "governance" mean different things to different actors in different world regions (Koff, 2016). For this reason, stakeholders and academics alike have worked to develop policy tools aimed at operationalizing sustainable development through concrete objectives and methodologies (Adams et al. 2004; Berry et al., 2012).
One of the most prominent and debated approaches to the implementation of sustainable development is "payment for ecosystem services", of which "payment for watershed services" (PWS) is one of the more well-known and widely practiced. While proponents argue that such payments provide market value to individuals or communities that promote and maintain the services that ecosystems provide humanity for development, opponents have claimed that this approach commodifies the environment and promotes inequalities, thus limiting its normative impact (Schomers, and Matzdorf, 2013). Very little middle ground exists between these positions. This article responds to the following research question: How can policy coherence for development (PCD) be operationalized as a methodology that can improve the effectiveness of PWS initiatives? "Effectiveness" is defined as the achievement of program objectives in line with the transformative development promoted by the 2030 Sustainable Development Agenda. It engages the limited "middle ground" in debates on PWS by proposing a means through which policymakers can address normative concerns associated with this policy tool.

The article has seven sections. Following this introduction, part two presents the objectives of the article. Part three then introduces PCD as a conceptual and methodological lens through which PWS is examined. Part four then reviews the literature on PWS and raises the most salient discussions in contemporary debates over this policy strategy. This is followed by part five that presents empirical results of PWS programs in the Antigua River Basin located in the center of the State of Veracruz in Mexico utilizing a PCD methodology. Finally, part six presents the discussion of empirical results followed by part seven which is the conclusion.

A novelty of this article is the operationalization of the PCD approach in a Water Basin. Thus far, attempts to improve the effectiveness of PWS programs have been dominated by measures aimed at improving social participation in the definition and implementation of these 
initiatives (Adams et al., 2004). Despite implementation of such approaches, PWS programs are still criticized for unintended negative social impacts (Ruiz-Mallén et al., 2015). This would suggest that other variables beyond social participation should be considered when analyzing PWS. This article addresses this gap by applying methodologies based on policy coherence for development (PCD) to PWS. By employing a PCD methodology, the article pursues two main objectives.

\section{OBJECTIVES}

First, this work aims to identify policy mechanisms that undermine the successful application of PWS programs so that stakeholders can make adjustments, thus, metaphorically ensuring that "the baby" (PWS) is not discarded with "the bathwater" (policy incoherence for sustainable development). Second, the article aims to reinforce our operationalization of sustainable development and innovate the way that PCD is utilized as a policy tool given the commitment to it by international organizations such as the United Nations (UN), European Union (EU) and Organization for Economic Co-operation and Development (OECD).

\section{MATERIALS AND METHODS}

\section{The Operationalization of PCD}

PCD has emerged as an important policy tool since the 1990s. Thus far, it has only been utilized as a policy framework for international donors. The EU adopted PCD with the Maastricht Treaty in 1993 and the Cotonou Partnership Agreement in 2000 (Laakso, et al. 2007). However, only in 2005 was PCD established on the EU agenda with the Commission adopting a communication with a focus on PCD and the EU Council adopting conclusions on PCD (Centre for European Policy Studies [CEPS], 2006). PCD was also integrated into the EU development policy program, (European Consensus on Development, EU, 2006). The Lisbon Treaty of 2009 further reinforced the European Union commitment to PCD, stating that 'the Union shall take account of development cooperation in policies that it implements which are likely to affect developing countries' (Art. 208). The EU is also committed to a biannual PCD reporting process (European Commission, 2007; 2011).

Similarly, PCD has been on the OECD agenda since the early 1990s. The 2002 Ministerial Statement (OECD Action for a Shared Development Agenda) points out that, when formulating policies across the policy spectrum, OECD countries should take account of the potential impact on developing countries. In response to the 2002 Ministerial Statement, the OECD launched a program on Policy Coherence for Development (OECD 2005). In 2008, ministers of OECD countries adopted the Declaration on Policy Coherence for Development (OECD 2009). The Development Assistance Committee (DAC) of the OECD, which includes most EU member countries and the European Union, has organized peer reviews of its member states' development policies, where policy coherence has received growing importance. In 2007, the Development Co-operation Directorate and the Development Centre of the OECD jointly created the OECD Network of National Focal Points for Policy Coherence for Development ('the PCD Network') 'to establish better communications between the OECD and officials in capitals on Policy Coherence for Development'. At the meeting on 9 February 2012 in Paris, the Network envisioned that PCD would be a core element of the new development paradigm (OECD 2012).

Globally, the United Nations has also adopted PCD. It is a pillar of the Sustainable Development Agenda and it is specifically referenced in Target 17.14 as one of the governance mechanisms through which the UN and member states are pursuing the implementation of the SDG's. In terms of natural resource management, the UN is promoting PCD through its CLEWS program (climate, land-use, energy and water) which examines how investments in one strategic resource affects the others.

While the UN, EU and the OECD have championed PCD internationally significant criticisms of its implementation remain prominent. First, scholars such as Siitonen (2016) have argued that the implementation of 
PCD by supranational organizations has been limited to their own policies or those of their own member states. In doing so, the tool has not been employed to detect incoherences that exist in parts of the world where development occurs. Moreover, because this tool has been implemented in a donor-centric way, Thede (2013) contends that it actually reinforces global inequalities by highlighting the differences between aid donors and aid recipients. Similarly, Koff and Maganda (2016) have shown how supranational organizations, such as the European Union, have employed PCD as a policy tool to improve the efficiency of their programs at the expense of normative change and global equity. Finally, Carbone and Keijzer (2016) have shown how PCD has been pursued through institutional reform more than policy implementation. By applying PCD analysis to PWS initiatives in Mexico within the framework of transformative change, this article addresses all of these concerns.
The article employs PCD analysis by adopting the eight different typologies of incoherences identified in the literature on PCD as methodological categories (Carbone, 2008; Koff, 2017; Koff et al. 2016), which are presented in table 1. In the field of sustainable development, PCD has received prominent attention in discussions on agricultural policy (Matthews, 2008; Carbone, 2009), fisheries (Kazcynski and Fluharty, 2002), biodiversity (Nilsson et al., 2012), energy (King et al., 2013), food security (Sarelin, 2007), climate change (Kok and de Coninck, 2007), water (Koff and Maganda, 2016) and the post-2015 agenda in general (Pilke \& Stocchetti, 2016; Millán, 2015). However, there is a dearth of analysis of sustainability with PCD as a methodology (rather than a goal unto itself), defined as the categorical analysis of public policy initiatives through the identification of different coherences/incoherences.

TABLE 1. Typologies of Policy Incoherence for Development.

\begin{tabular}{ll}
\hline Typology of Incoherence & Definition \\
\hline Horizontal incoherence & Incoherence between development aid and non-aid policies \\
\hline Vertical incoherence & $\begin{array}{l}\text { Incoherence between policies of regional organisations and member } \\
\text { states }\end{array}$ \\
\hline Inter-donor incoherence & $\begin{array}{l}\text { Incoherence between development policies of a region's different } \\
\text { member states }\end{array}$ \\
\hline Internal incoherence & $\begin{array}{l}\text { Inconsistencies between the objectives and means of a given policy (i.e. } \\
\text { measurement techniques) }\end{array}$ \\
\hline Inter-organisational incoherence & $\begin{array}{l}\text { Incoherence between the development policies of a donor country's } \\
\text { government and civil society organisations }\end{array}$ \\
\hline Multilateral incoherence & $\begin{array}{l}\text { Incompatibility between the development goals and procedural norms of } \\
\text { international organisations such as the EU, OECD, the UN, and the } \\
\text { international financial institutions }\end{array}$ \\
\hline Financial incoherence & $\begin{array}{l}\text { Incoherence between development funding in donor states and those in } \\
\text { aid receiving states }\end{array}$ \\
\hline Incoherence between policy strategies in development and non- \\
development policy arenas and core values of liberal \\
societies
\end{tabular}


This article argues that PCD can become innovative from a policy standpoint when applied to specific development contexts, such as water basins or clearly defined ecosystems. While current uses of PCD as a policy tool highlight its strengths because they prioritize sustainable development over competing policy arenas and they identify specific challenges regarding development policy implementation, contemporary approaches only scratch the surface of PCD's potential contributions to transformative development as defined above. Instead, the application of
PCD as a methodology to examine policies/programs at different scales of analysis could maximize its impact. This is explored here through the application of a PCD methodology to PWS initiatives in the Antigua river basin in part four below. This analysis is based on the modeling of PWS initiatives through the identification of internal and external (in)coherences based on the categories presented in table 1. This methodological model is presented in figure 1 and applied in section four below.

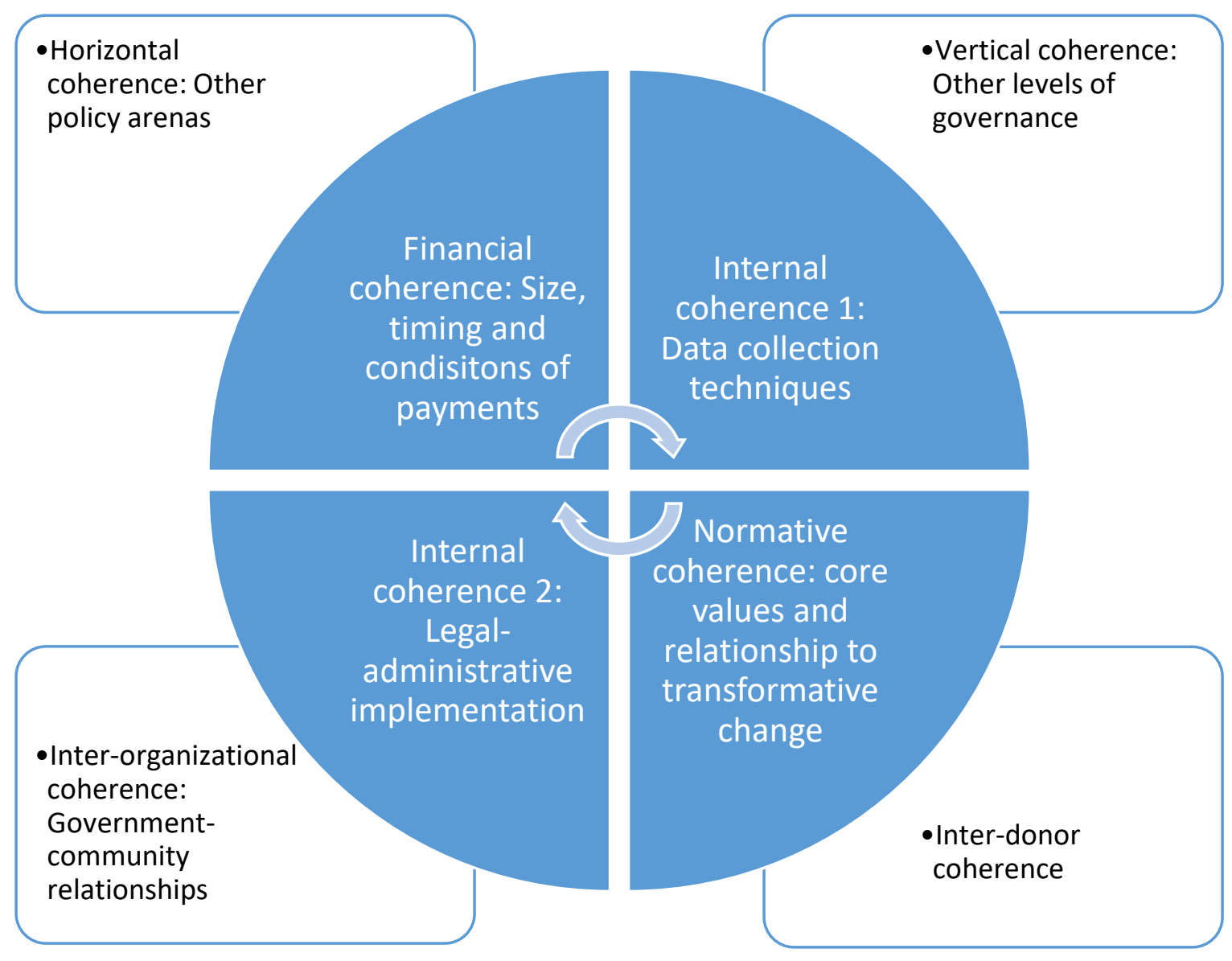

FIGURE 1. PCD as a methodological model for policy analysis.

Source: Figure designed by authors.

Note that the "multilateral coherence" category in table one has not been included in the model because it is specific to the international arena. 


\section{Research Design and Data Collection}

This work is part of a larger project entitled "Experimental Frameworks for Evaluating Net Effects of Hydrologic Service Payments on Coupled Social-Ecohydrological Systems" (CH2ILES), funded by the National Science Foundation (project number ICER/GEO 1313804), that examines PWS programs in the Antigua River Basin in the center of the Mexican state of Veracruz (Fig. 2), which can be considered a critical case for the study of PWS for a number of reasons:1) the PWS programs in the region are long running, 2) there is a diversity of PWS program types in the region, 3) there are many unanswered questions about how land use/land management change (the target of PWS) impacts the socio-ecological system, and 4) the project is providing a rich data set on which to assess PWS performance. Also, the city of Coatepec, Veracruz, located in the cited basin, is the site of the pilot initiative for PWS in Mexico named "Coatepec Trust for Forest and Water Conservation" (Fideicomiso Coatepecano para la Conservación del Bosque y el Agua, Fidecoagua), and is one of the matching program case studies in the CH2ILES research project. The second initiative in an adjacent sub-basin is the "Compensation Program for environmental services of the Pixquiac river watershed" (Prosapix). The Basin is also home to the national payment for watershed services run by Mexico's Forestry Commission (PSAH-Conafor) (Table 2).

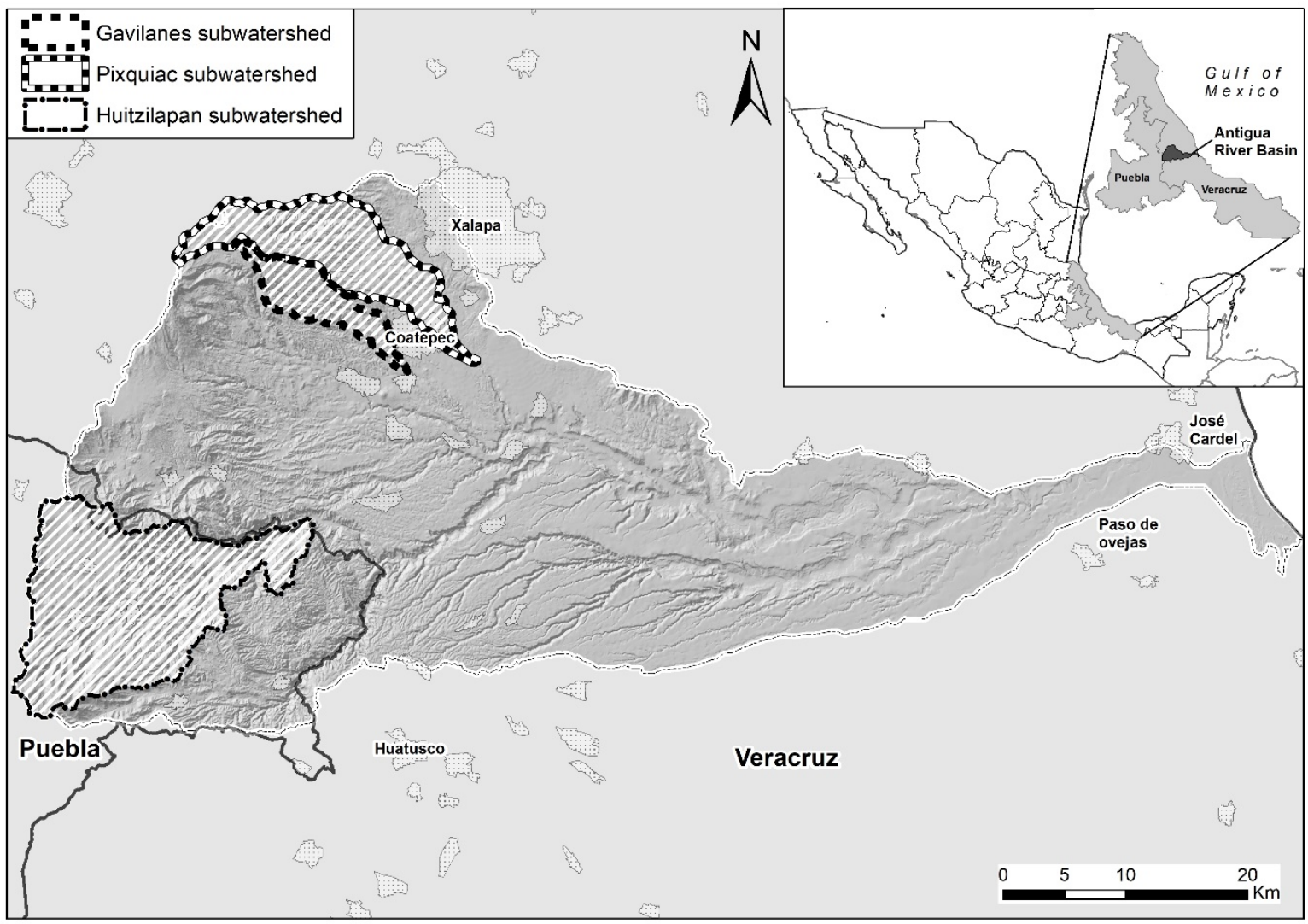

FIGURE 2. Location of the Antigua River Basin and subwatersheds Source: Map created by Juan Jose von Thaden Ugalde 
TABLE 2. Comparison of PWS Initiatives in the Antigua Basin.

\begin{tabular}{|c|c|c|c|}
\hline & PSAH-CONAFOR & FIDECOAGUA & PROSAPIX \\
\hline Objectives & $\begin{array}{l}\text { Create markets for } \\
\text { ecosystem services; pay } \\
\text { landowners to conserve } \\
\text { forests; decrease } \\
\text { poverty in forest areas }\end{array}$ & $\begin{array}{l}\text { Conserve forest resources } \\
\text { and maintain water } \\
\text { supplies of Coatepec; } \\
\text { prevent soil erosion and } \\
\text { damage to natural } \\
\text { resources }\end{array}$ & $\begin{array}{l}\text { Act as a financial instrument for } \\
\text { the holistic management of the } \\
\text { water basin; support the } \\
\text { conservation of all watershed } \\
\text { services through reforestation } \\
\text { and protection of natural } \\
\text { resources }\end{array}$ \\
\hline $\begin{array}{l}\text { Payments per } \\
\text { Hectare }(M X N)\end{array}$ & $\begin{array}{l}\text { 300/ha for forest land } \\
\text { 1100/ha for at-risk } \\
\text { deforestation zones }\end{array}$ & 1000/ha & 1100/ha \\
\hline $\begin{array}{l}\text { Type of } \\
\text { Compensation }\end{array}$ & Economic & Economic & $\begin{array}{l}\text { Economic plus Technical } \\
\text { Assistance }\end{array}$ \\
\hline Initial Budget & $200 \times 10^{6} \mathrm{MXN}(2002)$ & $1 \times 10^{6} \mathrm{MXN}(2003)$ & 300,000 MXN (2006) \\
\hline $\begin{array}{l}\text { Parameters for } \\
\text { payments }\end{array}$ & $\begin{array}{l}\text { Calculation of } \\
\text { opportunity costs of the } \\
\text { land for three agricultural } \\
\text { activities at the national } \\
\text { level }\end{array}$ & $\begin{array}{l}\text { Calculation of profits per } \\
\text { hectare earned by the } \\
\text { average number of coffee } \\
\text { producers in the region }\end{array}$ & $\begin{array}{l}\text { Calculation approximately } \\
\text { based on earnings from } \\
\text { livestock }\end{array}$ \\
\hline Financial Stability & Stable & Semi-stable & Unstable \\
\hline Activities & $\begin{array}{l}\text { Passive forest } \\
\text { conservation; best } \\
\text { practices in soil erosion }\end{array}$ & $\begin{array}{l}\text { Passive forest } \\
\text { conservation; forest } \\
\text { restoration }\end{array}$ & $\begin{array}{l}\text { Promotion of sustainable } \\
\text { management of wood and non- } \\
\text { wood natural resources; } \\
\text { capacity building and public } \\
\text { education around importance } \\
\text { of watersheds and the use of } \\
\text { their resources; seed funding } \\
\text { for projects on new forms of } \\
\text { production; forest restoration. }\end{array}$ \\
\hline
\end{tabular}

Source: Rodríguez Camargo, N. R. (2015) Chapter 4, p. 23.

Field research was carried in the Antigua Basin from January 2016 to March 2017. In order to operationalize PCD, research has been based on a review of the academic and professional literatures on PWS and PCD, as well as policy documents related to both development strategies in Veracruz and PWS programs in the Antigua Basin. New data has been generated through the organization of a roundtable including ten stakeholders (representatives of government agencies and non-governmental organizations (NGOs)) involved in PWS debates in the Antigua Basin which was organized within the IV Congreso Nacional de Manejo de Cuencas Hidrográficas (IV National Conference on the Management of Hydrographic Basins) held in Xalapa, Mexico, 26-28 October, 2016. Participants were recruited through previous contacts with different organizations and semi-structured questions were sent to them before the roundtable was held. Participants were also invited to submit questions as well. During the roundtable, the authors mediated the discussion by maintaining focus on the previously circulated questions. The debate was then opened to the public and participants were again invited to raise relevant queries.

A follow-up discussion was held with the panel participants in March 2017 in order to validate the research findings. On this occasion, a draft of the empirical findings was circulated to participants before the workshop in addition to a list of questions based on preliminary conclusions. Based on this draft and the list of questions, the discussions on PWS programs in the Antigua Basin was utilized to validate our findings. The responses of the 
participants in these two structured policy fora informed the empirical analysis presented in part three below.

Unlike traditional research on PWS which focuses specifically on those programs, a PCD approach is innovative because it considers the interaction between PWS and other policy arenas. The stakeholders interviewed in the policy forum and the follow-up meeting are government officials and representatives of NGOs that are active in both environmental and non-environmental policy arenas, such as forestry, water, climate change, agriculture, social integration and education. Stakeholders in the areas of security and commerce were invited to participate as well but they declined our invitation. Moreover, five semistructured interviews were carried out with academic experts on PWS, development in the state of Veracruz and agricultural and social policies; and four interviews were carried out with local entrepreneurs in sustainable tourism during a site visit. Between the policy fora and the individual interviews, nineteen stakeholders provided empirical information for this article.

\section{Debates over Payments for Watershed Services: Salient Issues and Competing Appreciations}

Payments for watershed services have emerged within the framework of the broader payment for ecological/ecosystem services (PES) movement. This approach provides economic incentives to landowners to engage in land management practices that conserve or restore ecological services. Such strategies emerged in the 1970s as a way to increase public interest in conservation of biodiversity (Gómez-Baggethun, de Groot, Lomas and Montes, 2009). As stated above, payment for watershed services is the fastest growing example of PES worldwide due to global concern regarding the decline of hydrological resources. By assigning a utilitarian value for environmental services, PES programs aim to provide financial rewards to compensate and set "decisions for nature" on a more equal footing with other economic considerations. These payment schemes seek to address water-related problems, such as scarcity or pollution by directly linking producers of watershed services to consumers through ways that explicitly incorporate market value to these services (Asbjornsen et al. 2015). Such programs have been promoted by international organizations (Kyoto Protocols), especially with focus on developing countries. According to Mayrand and Paquin (2004), Kosoy et al. (2007) and others (Alix-Garcia et al. 2005), over 300 PES programs have been established worldwide. In the broader scope of all ecosystem services, Costanza et al. (2014) estimate that the total global value of ecosystem services in 2011 was USD $125 \times 10^{12}$ year. Moreover, Milder et al. (2010) estimate that by the year 2030, markets for biodiversity conservation could contribute to poverty alleviation throughout the world by benefittinglow-income households in developing countries, carbon markets, markets for watershed protection, and markets for landscape beauty and recreation.

The literature specifically focusing on PWS programs has detailed the underlying economic logic of this policy approach. Wunder, Engel and Pagiola (2008) have shown how this strategy includes two payment approaches: 1) beneficiary-financed, under which the users of ecological services pay for them directly and 2) government financed, under which the government pays for ecological services on behalf of users (Wunder et al., 2008). The authors also contend that PWS are effective remedies for the mismanagement of watershed services. Other authors have focused on the indirect benefits of PWS programs. Muradian (2013) has shown how PWS can act as the basis of collective action aimed at environmental conservation. Garbach, Lubell and DeClerck (2012) focus their analysis on the ways that payments stimulate social communication between farmers.

Despite its emergence throughout the world, PWS strategies remain controversial for different reasons. First, no universal definition of "ecosystem service" or "watershed service" exists. Boyd and Banzhaf (2006) contend that such terms are too "ad hoc" to have meaningful value. Mokondoko et al. (2016) argue that the bundling of these services has restricted financing for PWS in Mexico by not making the argument of their importance 
for particular sectors. Similarly, the lack of definition of watershed services has been recognized in policy documents. The 2005 Millennium Ecosystem Assessment identified 24 different ecosystem services (Millennium Ecosystem Assessment, 2005) which are very different in character. These services vary from those related to food production to climate change, to energy, etc. The disparities between these fields has also led to criticisms related to the lack of integrated solutions provided by this policy approach (Wunder et al., 2008). Other studies have highlighted the negative influences of PWS (and PES more generally) on other arenas such as social inequality (Corbera et al., 2009; Börner et al., 2017), adaptation to global change (Murandian et al., 2013) and poverty alleviation (RuizMallén et al., 2015)

Of course, the conceptual confusion surrounding this term has led to methodological debates as scholars have criticized PWS approaches for their measurement difficulties. The assignment of economic values to watershed services is often contested for being a practice that is too subjective. Boyd and Banzhaf (2006) criticize such approaches for a lack of standardized environmental accounting units. Similarly, Redford and Adams (2009) argue that markets only exist for a certain range of ecosystem services, and some services are not amenable to pricing or valuation, thus complicating the implementation of the entire system. Boisvert et al. (2013) critically analyze market-based instruments for environmental protection and highlight the lack of attention paid to their design and impacts. Asbjornsen et al. (2015) have similarly underlined the lack of empirical studies that illustrate the impacts of PWS programs due to shortcomings related to monitoring and evaluation that reflect a lack of understanding of the complex interactions between market-based PWS and the coupled human and natural systems (CHANS) in which they operate. They also contend that monitoring of hydrological services is very expensive and that it is difficult to scale up models from micro-watersheds to watersheds leading to generalizations from policy makers that more forest leads to more service provision, which is a risky proposition in many cases (Asbjornsen et al. (2015).
Finally, PWS is often criticized in the literature for reasons related to its underlying logic as much as its operationalization. Scholars such as Redford and Adams (2009) and Shapiro-Garza (2013) have contended that economic approaches commodify the environment by placing a monetary value on resources that outweighs the non-economic value of nature. Moreover, scholars (Redford and Adams, 2009; Alix-Garcia et al. 2005) have identified inherent tension between efficiency, effectiveness and equity as program objectives. Related to this, numerous scholars have contended that PWS programs do not pay close enough attention to surrounding social contexts. For example, Muradian (2013) discusses the subjective nature of assigning monetary value to watershed services due to cultural considerations that affect how the communities value specific services. Moreover, Rodríguez de Francisco et al. (2013) empirically examined payments for ecological services in Ecuador and showed how these programs reinforced social divisions, eroded community organization and exacerbated inequalities because such programs interact with existing development trajectories and power differentials. Another viewpoint contends that the focus on social context and equity has actually hurt the efficiency of PES programs (Samii, et al. (2014).

These criticisms of PWS programs have led to a rejection of many of their fundamental tenets. For example, PWS is often promoted as a way to ensure conservation of natural resources/biodiversity, but also as a strategy for poverty alleviation, social integration, the promotion of resilience and the pursuit of food and water security. While some programs have achieved conservation, most reviews of PWS initiatives (Rodríguez de Francisco et al. 2013; Asbjornsen et al. 2015) highlight the approach's limits in terms of social impacts. This would seem to indicate that PWS strategies, as designed and implemented today, are incompatible with the transformative development objectives that characterize the 2030 Sustainable Development Agenda because the SDGs extend beyond simple conservation. The following section addresses this assumption and indicates how policy coherence for 
development (PCD) methodologies can be applied to PWS programs in a way that fosters more transformative change.

\section{RESULTS}

\section{Empirical Results: A PCD Approach to Transfor- mative Development within the Framework of PWS}

The previous section has outlined contemporary debates on PWS including the perceived weaknesses of current PWS strategies. However, as the 2030 Agenda for Sustainable Development promotes "transformative sustainable change," policy mechanisms that promote the implementation of the seventeen Sustainable Development Goals need to be identified. Critics of PWS claim that there is a dearth of scientific evidence legitimizing these programs and that their promotion is speculative. However, many of the proposed empirical studies of PWS (Milder et al. (2010), Zheng et al. (2013)) examine social and biophysical impacts in specific ecosystems/watersheds without necessarily studying the programs themselves. According to many scholars (Carpenter et al., 2009; Costanza et al. 2016) PWS and sustainable development as defined by the SDGs are not as separate as they seem. This article aims to fill this gap in the literature by proposing a policy coherence for development approach, which analyzes PWS within the framework of transformative development as defined by the SDGs. In this regard, the analysis will discuss PWS by examining its relevance in terms of conservation, social integration and sustainable economic development in communities where it is practiced. Empirical considerations are based on the data gathered during the public forum and follow-up meeting as well as empirical interviews mentioned above.

\section{Exploring the transformative potential of PWS in the Antigua River Basin Through PCD Analysis}

PWS has become a prominent mechanism in Mexico for addressing deforestation and water scarcity issues. These programs were initially proposed in 2003 in response to severe deforestation, overexploitation of aquifers and high poverty rates in rural areas. In this regard, PWS was linked to conservation and social integration objectives. The main objective of the Mexican PWS program was to prevent deforestation in poor and marginalized areas of hydrological importance. The program started with a clear focus on improving provision of hydrological services but over time it has been re-oriented toward a focus on socioeconomic issues (Muñoz-Piña et al. 2011): The project was run by Conafor, Mexico's National Forestry Commission which dispersed USD $384.6 \times 10^{6}$ between 2003 and 2011 (García Romero, 2012). It expanded the geographic coverage of PWS from 126000 hectares in 2003 to 330000 hectares in 2011 (García Romero, 2012). León et al. (2012) narrate the evolution of Mexico's PWS programs through the following stages:

1. Gestation. In this phase, a group of academics, some from within the government and others from numerous universities, proposed, designed, and promoted the program. At that time, the forest strategy was incomplete. It focused exclusively on forests with high commercial value but neglected well-preserved forests that had little or no commercial value.

2. Institutionalization and maturation. The model went through a second stage during which the implementation of PSAH [Acronym for Pagos por servicios ambientales hidrologicos: Spanish term for payment for environmental and hydrological services] in 2003 was followed by the incorporation of other environmental services such as carbon sequestration and biodiversity. In 2006 the Mexican government obtained international financing (a loan from the World Bank and a grant from the Global Environment Facility) that built up its financial and operational capacity. In that same year, the Program Technical Advisory Committee was integrated into the system in order to advise Conafor on the implementation of PES frameworks. Then, in 2007, the program received a huge influx of capital as its budget was increased from USD $18 \times 10^{6}$ to nearly USD $100 \times 10^{6}$.

3. Adjustments and expansion. The past ten years have been good to PSAH and it has entered a third stage of development. The program has a national 
perspective, which has clearly been positive but has limited the focused attention on regions that are a priority for the provision of environmental services. While the program does have targeting criteria, the total eligible land area is so large that it results in scattered payments and varying impact payments for the maintenance of these services, with the exception of natural protected areas. Indeed, the allocation criteria have influenced the targeting of payments in some areas, primarily natural protected areas, where 61 percent of the program's budget is designated. In addition, if we were to critique the program, we might point out that payments for non-use of resources alongside weak social capital may discourage local development processes. (León et al. 2012)

In terms of program implementation, the government and the owner of the forest sign a five-year contract whereby the owner receives a payment at the end of each year if the forest is conserved. The payment seeks to cover the opportunity costs for landowners of preserving the forest. The program focuses on areas where commercial forestry is not feasible, since there are other government programs that support sustainable commercial exploitations (García Romero, 2012). As with most PWS programs, it is difficult to ascertain how affective these initiatives have been. On one hand, the Mexican PWS program successfully prevented 18000 hectares from being deforested (OECD, 2014). However, this statistic represents only a small fraction of the geographic coverage of the program. (García Romero, 2012) Also, little progress was made in the fight against poverty in participating geographic areas. According to Rolón Sánchez (2009), the levels of marginalization in areas participating in PWS programs have not been significantly affected. The percentage of corresponding residents living in "very high" marginalization increased from $25 \%$ in 2003 to $37 \%$ in 2008 after reaching $50 \%$ in 2007. Those living in "high" marginalization decreased minimally from $47 \%$ to $45 \%$ during the same period. (Rolón Sánchez, 2009). Of course, the levels of marginalization are affected by many more variables than the existence of a PWS program.

$\mathrm{La}$ Antigua basin in the Mexican State of Veracruz is one of the more visible cases where PWS has been implemented (Fig. 2). A significant body of literature has been published on this case. Many authors have examined the impacts of PWS programs in the basin through different approaches including technical implementation (Scullion et al., 2011), spatial analyses (Mokondoko et al., 2018), institutional decentralization (Nava-López et al., 2018), social participation (Jones et al., 2019), etc. These works have contributed to significant understanding of the strengths and weaknesses of PWS in the basin. This article builds on this interesting research because it addresses the interactions between PWS and other policy areas.

$\mathrm{La}$ Antigua is a basin that extends $3918 \mathrm{~km}^{2}$ from the Gulf of Mexico to the center of the state. The basin is characterized by high biodiversity including pine-oak forest, cloud forest, deciduous forest, riparian vegetation, induced and cultivated pasture (Proyecto Conservación de Cuencas Costeras en el Contexto del Cambio Climático [C6], 2017). In addition to the wide variety of plants found in the different forests in the basin, numerous endemic fish and amphibian species live there. In terms of economic activities, the basin fosters shrimp farming, coffee (some under forest cover), cattle raising, sugar cane production and seasonal agriculture. Moreover, the sustainable tourism sector has begun to emerge around the Antigua river and its tributaries, where rafting and other outdoor sports have become popular.

According to the participants in the aforementioned policy forum, these economic activities, especially farming and the limited industry that exists in the basin have threatened the local ecosystem. The Antigua basin has its relevance at the national level since it has been declared by Instituto Nacional de Ecologia y Cambio Climático (INECC) and other researchers as a priority watershed due to its levels of degradation (Román-Jiménez et al., 2011), important number of users, and high amount of biodiversity (Cotler, et al., 2010). The Antigua river has been polluted by the runoff of chemicals used for agriculture and domestic use 
as well as waste associated with coffee production. Moreover, according to interviewees, clandestine logging (which contributes to deforestation), the uncertainties in coffee pricing, sugar cane expansion and a recent attempt to build a hydroelectric dam near the town of Jalcomulco, threaten sustainable tourism in the region which attracts more than 40000 visitors per year (personal interviews with tour operators and political organizers, 14 March 2016, Jalcomulco). Also, increased urbanization has promoted significant deforestation as the expansion of informal urban settlements around Xalapa (state capital of Veracruz) and the city of Coatepec has reduced cloud forest cover to only 7.6\% (Benítez et al., 2012). In general, land management is an issue in the area as the lower part of the basin is characterized by small parcels of land while larger communal holdings characterize the upper part of the basin. Often the divisions between properties have been unclear, leading to social tensions (conclusion expressed by stakeholder participating in October 2016 Policy Forum).

In response to water scarcity and deforestation, the Antigua Basin has become the site of three prominent PWS initiatives. The first is the local government program in Coatepec which was established by Fidecoagua. The second program is the national PSAH initiative run by Conafor and the third program (Prosapix) has been forwarded by the Comité de Cuenca del río Pixquiac (Cocupix) which is a collective of local social actors. Table 2 above compares these initiatives.

What is interesting about the simultaneous presence of these PWS programs in the Antigua watershed is the seeming institutional coherence that exists between them. Scholarship (Fuentes \& Paré, 2012; Vidriales-Chan \& Mateos, 2016) on the Antigua basin has shown how governmental and non-governmental actors have participated in Cocupix with a vision of promoting a holistic and integrated management of the basin and its resources. Moreover, the experts interviewed for this project confirmed that the three PWS schemes outlined above have been coordinated since 2011 when "concurrent funding" was introduced for initiatives that were supported by different programs so that funding became complementary rather than competitive. Finally, Fuentes and Paré have documented how Cocupix participated in the elaboration of the State of Veracruz's Sustainable Development Plan. From a PWS standpoint, these programs indicate significant levels of citizen input and social participation which should contribute to effective implementation. From a PCD standpoint, these measures indicate institutional commitments to policy coherence for development, which should successfully promote sustainable transformative development in basin communities.

Empirical research on conditions in the Antigua basin, however, has indicated that PWS has made little impact on socio-environmental conditions in local communities. Scullion et al. (2011) have reported that remote-sensing data show that deforestation was substantially lower on properties receiving PWS payments compared to properties not enrolled in the programs, but the programs did not prevent the net loss of forests within Coatepec. Similarly, Mokondoko et al. (2018) utilized spatial analysis to compare the impact of payments for hydrological services on delivery of hydrological services in the basin. The study illustrates that mismatches exist between PWS-targeted areas and geographic areas of priority. The authors highlight the need to improve ecological and socioeconomic targeting criteria. This conclusion was supported by the stakeholders interviewed in the follow-up meeting organized in March 2017.

Other analyses have shown that poverty remains high in forested areas, that urban-rural social divisions remain prominent and that the deterioration of water quality in program territories includes substantial increases in e-coli bacteria which augmented the incidence of disease in the basin (Mokondoko et al., 2016; Personal interviews with government officials).

Following general trends regarding research on PWS, local studies of these initiatives have focused on the distribution of economic costs and benefits of payment programs as well as the need for social participation in their definition and implementation in order to promote buy-in amongst potential contributors (especially water users). 
However, a preliminary PCD analysis of these programs based on the viewpoints of stakeholders expressed in the 2016 policy forum and the follow-up meeting in 2017, indicates that economic incentives and political participation are not the only factors that impact the success of these policies. According to the ten participants in these events and the five local experts interviewed for this project, numerous policy incoherences exist which undermine the success of PWS programs, especially in terms of transformative development. These incoherences are outlined in table 3 .

TAble 3. PCD Analysis of PWS Programs in the Antigua Basin*

\begin{tabular}{ll}
\hline Typology of incoherence & Indicator \\
\hline Horizontal Incoherence & $\begin{array}{l}\text { Livestock: No health regulations regarding access to water supplies: contamination; } \\
\text { Inadequate health codes regarding infectious diseases; Unclear land governance; Tax issues }\end{array}$ \\
\hline & CONAFOR backed PHS in Mexico at the expense of Hacienda (Mexico's Treasury \\
& $\begin{array}{l}\text { Department); CONAFOR maps programs using national data so it defines program areas } \\
\text { genertical Incoherence } \\
\text { municipalities. or the case of SAGARP which pays subsidies to breed sheep which eat the } \\
\text { plants subsidized by CONAFOR }\end{array}$ \\
\hline
\end{tabular}

Payments are made as subsidies which do not necessarily stimulate local investment in transformative sustainable economies or appropriate infrastructure, thus PWS programs are often undermined by systemic market failure; poorly defined criteria and objectives were

Internal Incoherence confusing to local government; insufficient time and staff to review satellite images of entire region (led to exclusion of some communities). Payments were also delayed or withheld. These actions contributed to a general lack of trust in government which erodes the potential of these programs.

Complicated relationships between ejidos and ejidatarios (especially on security and infrastructure); Issues related to legal bases of NGOs. Some members of ejidos refuse

Inter-organizational Incoherence payments because they create problems within families around inheritances. Problems of uniformly implementing programs in communities characterized by ejidos and those dominated by private landowners as there are important structural/cultural differences between ejidos and more general NGOs.

World Bank is investing USD39.5 × $10^{6}$ in conservation of coastal basins (Climate change);

Inter-donor Incoherence Nestlé is subsidizing large-scale coffee growers to substitute arabic beans with robusto for instant coffee (impacts ecosystem)

Because CONAFOR was given responsibility for disbursement of subsidies in 2003 at the

Financial Incoherence end of the fiscal year, the agency had only 3 months to pay $4 \times 10^{6} \mathrm{MXN}$; Payments are small, generally representing less than $3 \%$ of recipients' income. Payment schedules are not always respected.

The PHS focuses on conservation which does not resolve the problem of unsustainable

Normative Incoherence economic practices nor address poverty in the region (no transformative development); Marginalization de-prioritized, thus diminishing the transformative impacts of programs which are incoherent with the 2030 Sustainable Development Agenda.

"Multilateral Incoherence is not included in this analysis because this is a domestic case and therefore, it is not applicable.

Source: Table compiled by authors based on policy documents, academic studies and responses of ten stakeholders in the 2016 policy forum organized within the

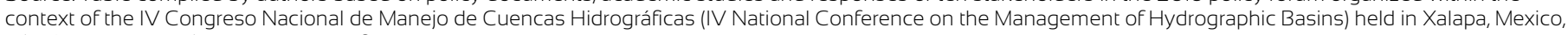
26-28 October, 2016 and March 2017 follow-up meeting. (see methodological statement). 
In terms of the conservation of the ecosystem, government officials who participated in the policy forum noted that PWS projects are weakened by horizontal incoherences, such as the absence of health and sanitation regulations for livestock which contaminate water, thus undermining PWS investments aimed at conserving water quality. Other examples of horizontal incorherences include inadequate public health strategies and contradicting subsidies such as those from Conafor and Sagarpa, as the former (Mexico's Forestry Commission) pays landholders to plant trees on their properties while the latter (Mexico's Agriculture Service) provides subsidies to promote the raising of goats which eat the saplings subsidized by Conafor (personal interview with development official, 23 June 2016, Xalapa). Other incoherences include: 1) internal incoherence as PWS programs include payment calendars that are not coherent with project evaluation calendars and different mapping techniques are used by national and local authorities which create mismatched information, 2) financial incoherence as the subsidies provided to participants in PWS schemes is reported to be less than 3\% of their total income (Scullion et al. 2011; 2016 policy forum). Conafor has decided since January 2017 to further reduce both the size of the subsidy and the duration (Deschamps-Ramírez, P., \& MadridZubirán, S., 2018), 3) inter-organizational incoherence as PWS programs in Mexico do not recognize the important cultural and structural differences between ejidos (communally managed agricultural lands) and more general civil society organizations, and 4) normative incoherence as PES focuses on conservation of natural resources without significantly addressing social marginalization, thus limiting the long-term transformative impacts of the programs. In fact, participants in the 2016 policy forum highlighted the fact that PWS subsidies do not promote economic transformations towards sustainability, but they have furthered financial dependence on public subsidies of marginalized communities in the basin. All of these incoherences, identified by local government officials and representatives of NGOs in the 2016 policy forum as well as interviewees, undermine the effectiveness or efficiency (or both) of PWS initiatives. Identifying these policy weaknesses in terms of incoherences already informs policymaking by suggesting where policies face challenges. However, this article contends that PCD analysis can provide a valuable tool for the reduction of policy obstacles that undermine PWS programs, thus, reinforcing their socio-environmental impacts. This is the focus of the discussion section.

\section{DISCUSSION}

The scholarship on PWS is rich and varied. However, most analyses of these programs contend that their success or failure depends on how they are designed and implemented within different socio-political contexts (review above). Such conclusions are irrefutable but how can recognition that PWS policies respond differently to different socioeconomic contexts aid progress toward transformative development through PWS initiatives? As such, the literature on PWS does not necessarily provide methodologies for addressing such concerns surrounding the design and implementation of successful PWS policies. This article contends that PCD can make a significant contribution towards the attainment of this objective.

PWS programs attempt to re-establish equilibrium in ecosystems by decreasing pressure on the producers of such services to operationalize their resources for commerce or by eliminating externalities (positive and negative) that promote environmental overexploitation. Moreover, PWS programs aim to address free-rider problems in that consumers of these services are meant to pay for them financially. This economic logic aims to elevate the value and public appreciation of watershed services.

As stated above, the literature on PWS programs has identified numerous policy difficulties that make this task difficult to achieve. This article contends that a PCD methodology would permit stakeholders to identify and categorize those variables that undermine PWS programs in order to isolate problems and address them. As figure 1 above shows, PCD accounts for both internal and external dimensions of policymaking. 
By attempting to establish PWS programs that ensure internal coherence (which can be controlled) and limit external incoherence for sustainable development (which cannot always be controlled), stakeholders can reinforce the transformative potential of these initiatives. Figure 3 illustrates this by applying the PCD methodology presented in figure 1 to PWS in the Antigua basin. The figure 3, based on the discussions held in the 2016 policy forum and 2017 follow-up meeting, illustrates how the PWS programs in the
Antigua are generally sound - both administratively and institutionally. For example, the "Conservation of Coastal Basins in the Context of Climate Change" (Conservación de Cuencas Costeras en el Contexto de Cambio Climático) (C6) project (which has a broader mandate than the implementation of PWS) unites actors from different institutions in a dialogue aimed at establishing a common vision of integrated basin management. Thus, PWS in this basin is characterized by vertical coherence and internal

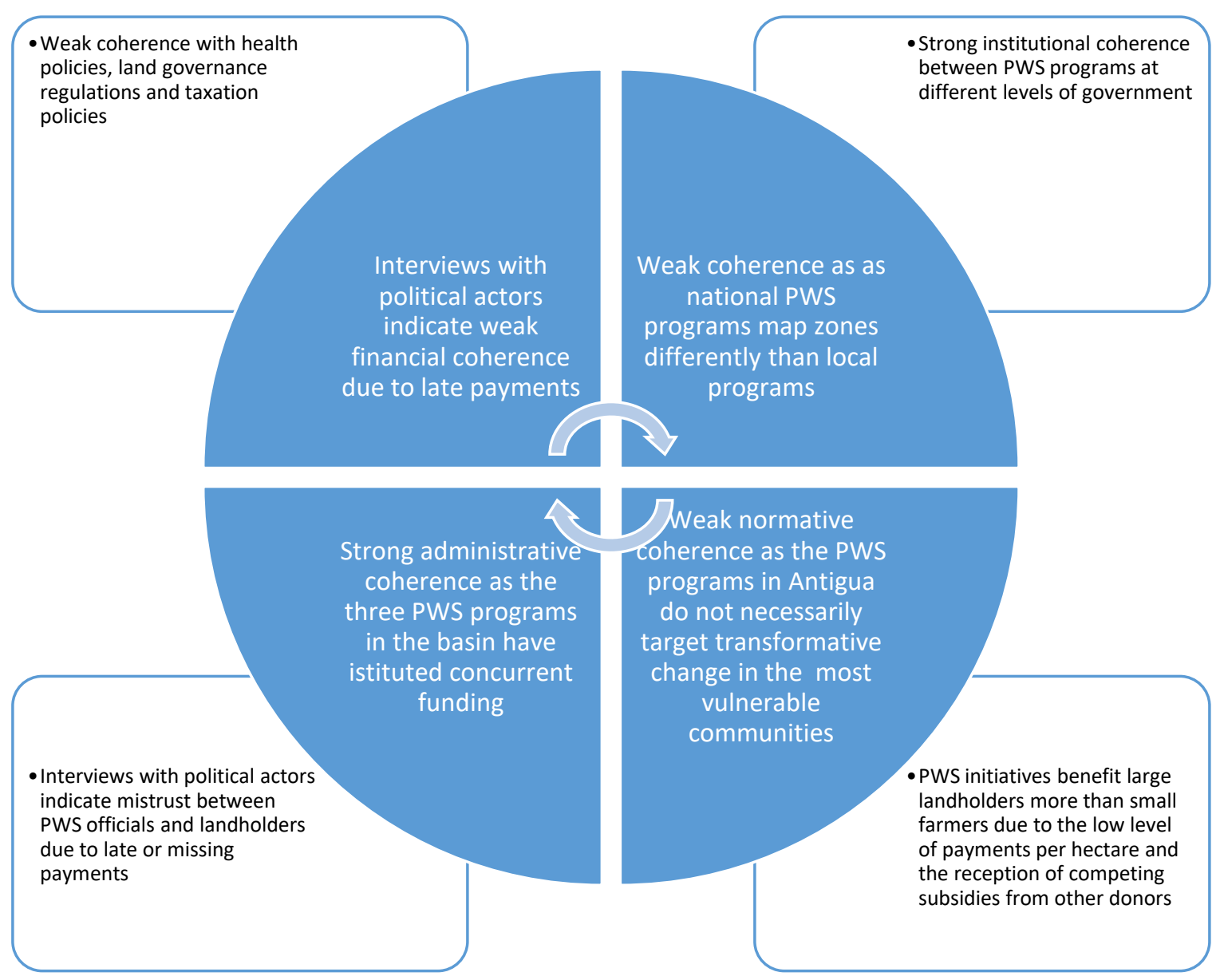

FIGURE 3. PCD as a model for policy implementation in the Antigua Water Basin.

Source: Figure designed by authors based on responses of ten stakeholders in the 2016 policy forum organized within the context of the IV Congreso Nacional de Manejo de Cuencas Hidrográficas (IV National Conference on the Management of Hydrographic Basins) held in Xalapa, Mexico, 26-28 October, 2016 and March 2017 follow-up meeting. 
coherence in terms of legal and administrative implementation. However, the discussions in the policy forum showed how many PWS initiatives in the basin are characterized by financial incoherence that has spilled over to contribute to important inter-donor, inter-organizational and above all, normative incoherences. This has severely hindered the transformative potential of PWS in the Antigua Basin as financial incoherence has led to dependence on subsidies and the poor management of these subsidies has actually contributed to social marginalization processes. In terms of the external dimensions of PCD, horizontal incoherence is above all visible in relation to health, farming and logging regulations, the latter two of which are also affected by financial incoherence related to subsidies, zoning and taxation. This approach would suggest that more coherent financial approaches to PWS in terms of the size of subsidies, payment calendars, coordination with non-PWS donors and above all, economic development strategies (including other subsidies, zoning and taxation) would reinforce the transformational impact of these initiatives by reducing waste and promoting sustainable livelihoods in target communities rather than subsidy dependence.

\section{CONCLUSIONS}

The research presented above has suggested that PWS programs have not been able to promote transformational development consistent with the 2030 Sustainable Development Agenda. Above all, PWS programs remain limited to government payments for resource conservation. Even though this goal is admirable, such approaches actually reinforce the dependence of vulnerable communities on government subsidies, thus undermining the Sustainable Development Goals'. Such criticisms of PWS undermine this policy approach to the extent that many critics call for its elimination. This article asks, however, whether such measures would lead us to metaphorically discard the policy baby with the incoherence bathwater. The literature review above has illustrated how most scholarship on PWS calls for further social participation in the design and implementation of such programs. However, opening poorly designed programs to public input will not improve the efficiency, effectiveness or sustainable impact of such initiatives. Moreover, increased public participation will not necessarily advance the PWS contributions to the transformative development pursued by the SDGs.

The operationalization of PCD as a policy methodology could help us to surpass the current limits of PWS initiatives by identifying specific internal and external mechanisms that undermine PWS programs and the relationships between them. In the case of the Antigua Basin, for example, financial and inter-organizational incoherence that characterizes PWS programs could be addressed through stronger policy partnerships including Conafor (PWS), Sedesol (Mexico's Secretariat for Social Protection, which is responsible for all federal anti-poverty and social development programs), Segarpa, NGOs and ejidos. The resulting improved combination of social development programs (Sedesol) with PWS, and integrated approaches to policy definition, implementation (including funding) and evaluation, would establish long-term normative coherence aimed at transformative sustainable development.

This analysis suggests that the establishment of a PCD methodology and the identification of specific policy incoherence mechanisms could provide fruitful bases for the monitoring and evaluation of PWS within specific socio-cultural and environmental contexts, such as river basins as called for in the political and academic literatures on PWS. PCD could also promote systemic comparison of PWS performance through the establishment of a methodological framework for policy comparison. By implementing PCD analysis of PWS, stakeholders can pinpoint specific policy strengths and weaknesses, identify

1 The NGO, Senderos y Encuentros para un Desarrollo Autónomo Sustentable (SENDAS) has begun offering technical assistance and organizing awareness campaigns as part of their communitarian projects, in order to reduce dependence on subsidies in the Antigua basin. These initiatives still are in their initial stages (Policy Forum organized in March 2017) 
specific points of spillover and address them accordingly. Moreover, the application of PCD to PWS initiatives reinforces the operational value of this policy tool, which thus far has been limited to only partial use by certain supranational organizations, such as the OECD and the EU. Finally, the application of PCD to PWS would strengthen the normative value of both instruments because it would further prioritize transformative sustainable development as a policy objective and consequently, the 2030 Sustainable Development Agenda would be the most important beneficiary of this innovative policy approach.

\section{REFERENCES}

Adams, W. M., Aveling, R., Brockington, D., Dickson, B., Elliott, J., Hutton, J., .., \& Wolmer, W. (2004). Biodiversity conservation and the eradication of poverty. Science, 306(5699), 1146-1149. doi: 10.1126/science. 1097920

Adger, W. N., Brown, K., Fairbrass, J., Jordan, A., Paavola, J., Rosendo, S., \& Seyfang, G. (2003). Governance for sustainability: towards a 'thick'analysis of environmental decision making. Environment and Planning A, 35(6), 1095-1110. doi: 10.1068/a35289

Alix-Garcia, J., De Janvry, A., \& Sadoulet, E. (2005). A tale of two communities: explaining deforestation in Mexico. World Development, 33(2), 219-235. doi: 10.1016/j.worlddev.2004.07.010

Asbjornsen, H., Mayer, A. S., Jones, K. W., Selfa, T., Saenz, L., Kolka, R. K., \& Halvorsen, K. E. (2015). Assessing impacts of payments for watershed services on sustainability in coupled human and natural systems. BioScience, 65(6), 579-591. doi: 10.1093/biosci/biv051

Benítez, G., Pérez-Vázquez, A., Nava-Tablada, M., Equihua, M., \& Álvarez-Palacios, J. L. (2012). Urban expansion and the environmental effects of informal settlements on the outskirts of Xalapa city, Veracruz, Mexico. Environment and Urbanization, 4(1), 149-166. doi: 10.1177\%2F0956247812437520

Berry, K., Saito, L. Kauneckis, D. \& Berry, K. (2012). Understanding perceptions of successful cooperation on water quality issues. Regions \& Cohesion, 2(2), 57-82. doi: 10.3167/reco.2012.020204

Boisvert, V., Méral, P., \& Froger, G. (2013). Market-based instruments for ecosystem services: institutional innovation or renovation? Society \& Natural Resources, 26(10), 1122-1136.

Börner, J., Baylis, K., Corbera, E., Ezzine-de-Blas, D., Honey-Rosés, J., Persson, U.M., \& Wunder, S. (2017). The effectiveness of payment for environmental services. World Development, 96, 359374. doi: 10.1080/08941920.2013.820815

Boyd, J. \& Banzhaf, H.S. (2006). What are ecosystem services? The need for standardized environmental accounting units. SSRN papers. Resources for the Future, Discussion Paper No. RFF DP 06-02. doi: 10.1016/j.ecolecon.2007.01.002

Brundtland Commission. (1987). Our common future. Oxford: Oxford University Press.

Proyecto Conservación de Cuencas Costeras en el Contexto del Cambio Climático [C6]. (2017). Plan de Acción de Manejo Integral (PAMIC) Cuenca del Río Jamapa, 1ª Edición junio 2017. Interinstitutional Project C6 "Cuencas Costeras", by SEMARNAT, CONANP, CONAFOR, INECC, FMCN, FMAM \& FGM. http://www.c6.org.mx/wpcontent/uploads/2017/06/JAM-PAMIC-web9Jun17baja.pdf (accessed 10 September 2018)

Carbone, M. (2008). Mission Impossible: The European Union and Policy Coherence for Development. Journal of European Integration, 30(3), 323-342. doi: 10.1080/07036330802144992

Carbone, M. \& Keijzer, N. (2016). The European Union and policy coherence for development: Reforms, results, resistance. The European Journal of Development Research, 28(1), 30-43. doi: $10.1057 /$ ejdr.2015.72

Carpenter, S.R., Mooney, H.A., Agard, J., Capistrano D., DeFries, R.S., Díaz, S., Dietz, T., Duraiappah, A.K., Oteng-Yeboah, A., Miguel Pereira, H., Perrings, C., Reid, W.V., Sarukhan, J., Scholes R.J. \& Whyte. A. (2009). Science for managing ecosystem services: Beyond the Millennium Ecosystem Assessment, PNAS 2009, 106(5), 1305-1312; doi: 10.1073/pnas.0808772106

CEPS. (2006). Policy Coherence for Development in the EU Council: Strategies for the Way Forward. Brussels: CEPS.

Corbera, E., Soberanis C.G. \& Brown K. (2009). Institutional dimensions of Payments for Ecosystem Services: An analysis of Mexico's carbon forestry programme. Ecological Economics, 68(3), 743-761. doi: 10.1016/j.ecolecon.2008.06.008

Costanza, R., Daly, L., Fioramonti, L., Giovannini, E., Kubiszewski, I., Mortensen, L. F. \& Wilkinson, R. (2016). Modelling and measuring sustainable wellbeing in connection with the UN Sustainable Development Goals. Ecological Economics, 130, 350355. doi: 10.1016/j.ecolecon.2016.07.009

Costanza, R., de Groot, R., Sutton, P., van der Ploeg, S., Anderson, S., Kubiszewski, I., Farber, S. \& Turner, R. (2014). Changes in the global value of ecosystem services. Global Environmental Change, 26, 152-158. doi: 10.1016/j.gloenvcha.2014.04.002 
Cotler H., Garrido, A., Bunge, V. \& Cuevas, M.L. (2010). Las cuencas hidrográficas de México: Priorización y toma de decisiones. In Las cuencas hidrográficas de México: diagnóstico y priorización, ed. H. Cotler. pp. 210-215. Instituto Nacional de Ecología-Fundación Gonzalo Río Arronte I.A.P. México D.F., México.

Deschamps-Ramírez, P. \& Madrid-Zubirán, S. (2018). Subsidios forestales sin rumbo. Apuntes para una politica en favor de las comunidades y sus bosques. Consejo Civil Mexicano para la Silvicultura Sostenible, AC. http://www.ccmss.org.mx/wp-content/uploads/2018/12 /Subsidios-forestales-sin-rumbo_2010_2017.pdf (accessed 15 December 2018)

European Commission (2007). EU Report on Policy Coherence for Development. Brussels: European Commission COM 545.

European Commission (2010). Policy Coherence for Development Work Programme 2010-2013. Brussels: European Commission, SEC, 2010, 421.

European Commission (2011). EU 2011 Report on Policy Coberence for Development. Brussels: European Commission, SEC, 1627.

European Union (2007). The European Consensus for Development 2006. Joint declaration by the Council and the representatives of the governments of the Member States meeting within the Council, the European Parliament and the Commission on the development policy of the European Union entitled "The European Consensus" [Official Journal C 46 of 24.2.2006]. https:// eur-lex.europa.eu/legal-content/EN/TXT/HTML/?uri =LEGISSUM:r12544\&from=EN (accessed 15 January 2019)

Ferraro, P. \& Kiss, A. (2002). Direct payments to conserve biodiversity. Science, 298, 1718-1719. doi: 10.1126/science.1078104

Fuentes-Pangtay, T. (2009). Análisis de los programas de pago o compensación por servicios ambientales en la cuenca del Pixquiac. Fortalezas y debilidades en el contexto local. México: Sendas A.C.

Fuentes-Pangtay, T. \& L. Paré. (2012). El Comité de cuenca del río Pixquiac: ensayos para crear una plataforma social de cogestión y su instrumento de financiamiento. In Al filo del agua: cogestión de la subcuenca del río Pixquiac (pp. 192-218), L. Paré \& P. Gerez (Eds.). Mexico D.F.: Juan Pablo Editores.

Garbach, K., Lubell, M., \& DeClerck, F.A. (2012). Payment for ecosystem services: the roles of positive incentives and information sharing in stimulating adoption of silvopastoral conservation practices. Agriculture, ecosystems \& environment, 156, 27-36. doi: 10.1016/j.agee.2012.04.017

García Romero, H. (2012). Payments for Environmental Services: Can They Work?

The Case of Mexico. Field Actions Science Reports, Special Issue 6. http:/ / factsreports.revues.org/1711
Gómez-Baggethun, E., De Groot, R., Lomas, P. L., \& Montes, C. (2010). The history of ecosystem services in economic theory and practice: from early notions to markets and payment schemes. Ecological economics, 69(6), 1209-1218. doi: 10.1016/j.ecolecon.2009.11.007

Hoebink, P. (1999). Coherence and development policy: the case of the European Union. In: Policy coherence in development co-operation (pp. 323-345), J. Foster \& O. Stokke (Eds.). London: Frank Cass.

Jones, K., Avila Foucat, S., Pischke, E., Salconea, J., Torrez, D., Selfa, T., \& Halvorsen, K. E. (2019). Exploring the connections between participation in and benefits from payments for hydrological services programs in Veracruz State, Mexico. Ecosystem Services, 35, 32-42. doi: 10.1016/j.ecoser.2018.11.004

Jordan, A. (2008). The governance of sustainable development: taking stock and looking forwards. Environment and planning C: Government and policy, 26(1), 17-33. doi: 10.1068\%2Fcav6

Kazcynski, V. \& Fluharty, D. (2002). European policies in West Africa: who benefits from fisheries agreements? Marine Policy, 26, 75-93. doi: 10.1016/S0308-597X(01)00039-2

King, C., Stillwell, A., Twomey, K., \& Webber, M. (2013). Coherence between water and energy policies. Natural Resources Journal, 53 , 117-215.

Koff, H. (2017). Diaspora philanthropy in the context of Policy Coherence for Development: Implications for the post-2015 Sustainable Development Agenda. International Migration, 55 (1), 5-19. doi: 10.1111/imig.12277

Koff, H. (2016). Reconciling competing globalizations through regionalisms? Environmental security in the framework of expanding security norms and narrowing security policies, Globalizations, $\quad$ 13(6), 664-682. doi: 10.1080/14747731.2015.1133044

Koff, H., Equihua-Zamora, M., Maganda, C., \& Perez-Maqueo, O. (2016). Ecosystem integrity and policy coherence for development: Tools aimed at achieving balance as the basis for transformative development. Regions \& Cohesion, 6(3), 77-92. doi: $10.3167 /$ reco.2016.060304

Koff, H. \& Maganda, C. (2016). The EU and the human right to water and sanitation: Normative coherence as the key for transformative change. European Journal for Development Research, 28(1), 90-110. doi: http://dx.doi.org/10.1057/ejdr.2015.77

Kosoy, N., Martinez-Tuna, M., Muradian, R., \& Martinez-Alier, J. (2007). Payments for environmental services in watersheds: Insights from a comparative study of three cases in Central America. Ecological economics, 61(2), 446-455. doi: 10.1016/j.ecolecon.2006.03.016 
Laakso, L., Kivimäaki, T., \& Seppäanen, M. (2007). Evaluation of Coordination and Coherence in the application of Article 96 of the Cotonon Partnership Agreement. Amsterdam: Aksant Academic Publishers.

León, C., Bauche, P., Graf, S., Cortina, S., \& Frausto, J. M. (2012). Replicating policy that works: Payment for environmental services in Mexico. Solutions, 3(5), 82-88.

Marks, G. (1993). Structural policy and multi-level governance in the EC. In A. Cafruny \& G. Rosenthal (Eds.), The state of the European community: The maastricht debate and beyond (pp. 391-411). Boulder, CO: Longman.

Martens, J. (2015). Benchmarks for a truly universal Post-2015 Agenda for Sustainable Development. Regions \& Cohesion, 5(1), 73-94. doi: $10.3167 /$ reco. 2015.050105

Matthews, A. (2008). The European Union's Common Agricultural Policy and Developing Countries: The Struggle for Coherence. Journal of European Integration, 30(3), 381-399. doi: $10.1080 / 07036330802141998$

Mayrand K. \& Paquin, M. (2004). Payments for environmental services: A survey and assesment of current schemes. Montreal: Unisfera International Centre for the Commission of Environmental Cooperation of North America.

Milder, J., Scherr, S., \& Bracer, C. (2010). Trends and future potential of payment for ecosystem services to alleviate rural poverty in developing countries. Ecology and Society, 15(2).

Millán, N. (2015). Un análisis de la Agenda Post 2015 desde la perspectiva de la coherencia de políticas. Relaciones Internacionales, 28, 81-104.

Mokondoko, P. \& Manson, R. (2010). Valoración de servicios ambientales hidrológicos: Caso río la Antigua. Ciencia, Tecnología e Innovación para el Desarrollo de México, 3(62), 26 de septiembre.

Mokondoko, P., Manson R., \& Pérez-Maqueo, O. (2016). Assessing the service of water quality regulation by quantifying the effects of land use on water quality and public health in central Veracruz, Mexico. Ecosystem Services, 22, 161-173. doi: 10.1016/j.ecoser.2016.09.001

Mokondoko, P., Manson, R., Ricketts, T. H., \& Geissert, D. (2018). Spatial analysis of ecosystem service relationships to improve targeting of payments for hydrological services. PLOS ONE, 13(2) 1-27. doi: 10.1371/journal.pone.0192560

Muradian, R. (2013). Payments for ecosystem services as incentives for collective action. Society \& Natural Resources, 26(10), 1155-1169.

Nava-López, M., Selfa, T., Cordoba, D., Pischke, E., Torrez, D., ÁvilaFoucat, S., Halvorsen, K. E., \& Maganda, C. (2018). Decentralizing payments for hydrological services programs in
Veracruz, Mexico: Challenges and implications for long-term sustainability. Society \& Natural Resources, 31(12), 1389-1399. doi: 10.1080/08941920.2018.1463420

Nilsson, M., Zamparutti, T., Petersen, J.E., Nykvist, B., Rudberg, P., \& McGuinn, J. (2012). Understanding Policy Coherence: Analytical Framework and Examples of Sector-Environment Policy Interactions in the EU. Environmental Policy and Governance, 22(6), 395-423. doi: 10.1002/eet.1589

Organisation for Economic Co-operation and Development [OECD] (2009). Building Blocks for Policy Coherence for Development. Paris: OECD.

Organisation for Economic Co-operation and Development [OECD] (2012). Meeting summary record. Meeting of the National Focal Points for Policy Coherence for Development. (SG/PCD/M(2012)1). Paris, France: OECD.

Organisation for Economic Co-operation and Development [OECD] (2014). Evaluaciones de la OCDE sobre el desempeño ambiental: México 2013, Análisis de los resultados medioambientales. Paris: OECD Publishing. doi.org/10.1787/9789264189188-es

Pagiola, S., Landell-Mills, N., \& Bishop, J. (2002). Market-based mechanisms for forest conservation and development. In S. Pagiola, N. Landell-Mills, \& J. Bishop (Eds.), Selling forest environmental services. London: Earthscan.

Paré, L. \& Gerez, P. (2012). Al filo del agua: cogestión de la subcuenca del río Pixquiac, Veracruz: Mexico, D.F.: UNAM.

Pilke, R. \& Stocchetti, M. (2016). Inequality and poverty: The ill-fitting pieces in the EU's development partnerships. Regions \& Cohesion, 6(1), 1-22. doi: 10.3167/reco.2016.060101.

Redford, K. H. \& Adams, W.M. (2009). Payment for ecosystem services and the challenge of saving nature. Conservation Biology, 23(4), 785787. doi: $10.1111 /$ j.1523-1739.2009.01271.x

Rodríguez Camargo, N. R. (2015). Análisis del costo de oportunidad de la tierra en la subcuenca del Ría Pixquiac, Una aproximacion del valor económico de los servicios ambientales hidrológicos como mecanismos para la conservación. Masters thesis, Universidad Veracruzana, Xalapa, Veracruz, Mexico.

Rodríguez de Francisco, J. C., Budds, J., \& Boelens, R. (2013). Payment for environmental services and unequal resource control in Pimampiro, Ecuador. Society \& Natural Resources, 26(10), 12171233. doi: 10.1080/08941920.2013.825037

Rolón Sánchez, E. (2009). Situación actual y futura de los pagos por servicios ambientales en México: el caso de hidrológicos. Retrieved form http://www.inecc.gob.mx/descargas/con_eco /2009_sem_ser_amb_pres_03_erolon.pdf 
Román-Jiménez, A. R., Mendoza-Briseño, M. A., Velázquez-Martínez, A., Martínez-Ménez, M. R., Torres-Rojo, J. M., \& RamírezMaldonado, H. (2011). Usos y riesgos del agua en la cuenca La Antigua, Veracruz, México. Madera y Bosques, 17(3), 29-48. doi: $10.21829 /$ myb.2011.1731141

Ruiz-Mallén, I., Corbera, E., Calvo-Boyero, D., \& Reyes-García, V. (2015). Participatory scenarios to explore local adaptation to global change in biosphere reserves: experiences from Bolivia and Mexico. Environmental Science and Policy, 54, 398-408. doi: 10.1016/j.envsci.2015.07.027

Sarelin, A. L. (2007). Human rights-based approaches to development cooperation, HIV/AIDS, and food security. Human Rights Quarterly, 29(2), 460-488. doi: http:/ /dx.doi.org/10.1353/hrq.2007.0022

Scullion, J., Thomas, C., Vogt, K., Pérez-Maqueo, O., \& Logsdon, M. (2011). Evaluating the environmental impact of payments for ecosystem services in Coatepec (Mexico) using remote sensing and on-site interviews. Environmental Conservation, 38(4), 426-434. doi: 10.1017/S037689291100052X

Shapiro-Garza, E. (2013). Contesting the market-based nature of Mexico's national payments for ecosystem services programs: Four sites of articulation and hybridization. Geoforum, 46, 5-15. doi: 10.1016/j.geoforum.2012.11.018

Schomers, S. \& Matzdorf, B. (2013). Payments for ecosystem services: A review and comparison of developing and industrialized countries. Ecosystem Services, 6, 16-30. doi: 10.1016/j.ecoser.2013.01.002

Sendas A.C. (2003). Senderos y Encuentros para un Desarrollo Autónomo y Sustentable. Delimitación de zonas prioritarias y evaluación de los mecanismos existentes para el pago de servicios ambientales hidrológicos en la cuenca del río Pixquiac, Veracruq, México. Project Technical Document: NCMA3-08-03.

Siitonen, L. (2016). Theorising politics behind Policy Coherence for Development (PCD). European Journal of Development Research, 28(1), 1-12. doi: 10.1057/ejdr.2015.76

Thede, N. (2013). Policy coherence for development and securitisation: competing paradigms or stabilising North-South hierarchies? Third World Quarterly, 34(5), 784-799. doi: http://dx.doi.org/10.1080/01436597.2013.800752
United Nations (2015). Transforming our world: the 2030 Agenda for Sustainable Development. Retrieved from: https://sustainable development.un.org/post2015/transformingourworld

Vidriales-Chan, G., \& Mateos, M. L. L. (2016). Gestión compartida de la subcuenca del río Pixquiac: conexiones desde la montaña. In $\mathrm{H}$. V. Narave-Flores, L. Garibay-Pardo, M. Á. Chamorro-Zárate, L. R. Álvarez-Oseguera, \& Y. de la Cruz Elizondo (Eds.). El Cofre de Perote: situación, perspectivas e importancia (pp. 42-48). Veracruz: Universidad Veracruzana.

Wunder, S., Engel, S., \& Pagiola, S. (2008). Taking stock: A comparative analysis of payments for environmental services programs in developed and developing countries. Ecological Economics, 65(May), 834-852. doi: 10.1016/j.ecolecon.2008.03.010

Zheng, H., Robinson, B. E., Liang, Y. C., Polasky, S., M. C., Wang, F. C., Ruckelshaus, M., Ouyang, Z. Y., \& Daily, G. C. (2013). Benefits, costs, and livelihood implications of a regional payment for ecosystem service program. Proceedings of the National Academy of Sciences of the United States of America, 110(41), 16681-16686. doi: 10.1073/pnas.1312324110.

Received: 16 October 2018

Accepted: 11 April 2019

Published: 13 December 2019

This paper must be cited as:

Koff, H. \& Maganda, C. (2019). Saving the baby while discarding the bathwater: the application of policy coherence for development analysis to payment for watershed services. Madera y Bosques, 25(3), e2531760. doi: 10.21829/myb.2019.2531760

Madera y Bosques by Instituto de Ecología, A.C. is distributed under a Creative Commons Licence Attribution-NonCommercial-ShareAlike $\quad 4.0$ Internacional. 